\title{
The Convergence of Household Consumption Expenditure Structure: Implications on Environmental Impact in Lithuania
}

\author{
Genovaitė Liobikienė, Romualdas Juknys \\ Vytautas Magnus University, Department of Environmental Science, Vileikos 8, Kaunas, Lithuania, \\ cross ref http://dx.doi.org/10.5755/j01.erem.60.2.1198
}

(received in February, 2012, accepted in June, 2012)

\begin{abstract}
The aim of this study is to examine Lithuanian household consumption changes, their convergence within the EU-15 and implications for the environmental impact. During the period of 1995-2007 the household consumption in Lithuania rose up 2.7 times. Substantial growth of consumption expenditure was observed to luxuries such as recreation, culture, education, while the slowest growth - to necessities such as food and housing. During the analyzed period Lithuania converged towards the Old Member States by two thirds of the household consumption structure categories. Response of the most consumption categories considered as necessities (food, housing, etc.) to growth of the income was inelastic i.e. consumption in these categories grew up slower than the income. On the contrary, elastic response of consumption categories considered as luxuries (recreation and culture, miscellaneous goods and services, education) to the income increase was characteristic i.e. their consumption grew up faster than the income. Whereas, during the period of 1995-2007 the biggest growth of consumption was characteristic of both the consumption categories with lower environmental impact, referring to the EEA (2010) emission intensities calculation and the changes in consumption structure which decelerated an increase in emissions of greenhouse gases by $19 \%$, and acidifying compounds by $6 \%$.
\end{abstract}

Keywords: household consumption, convergence, elasticity, environmental impact.

\section{Introduction}

Sustainable consumption and production are arguably the most challenging aspects of sustainable development (Jackson 2006, Kuhndt 2008, Nash 2009). Over recent decades consumption patterns and lifestyle in developed countries have become much more materially intensive and present an essential threat to sustainability. R. Kok et al. (2006) show that largest part of environmental load is allocated to household consumption. A. C. Kerkhof et al. (2009) have confirmed that the environmental impact increases hand in hand with growing household consumption. However, the distinct household consumption categories have different environmental impact (Kerkhof, Nonhebel, Moll 2009, EEA 2010, Feng, et. al. 2011), while changes in structure of household consumption can lead to the essential changes in consumption related environmental impact.

In the integration process to the EU Lithuania approached the Old Member States (EU-15) agreeably to GDP, comparative price level and total household consumption expenditure (Liobikiene, Mandravickaite 2011). As far as the structure of household consumption expenditure is concerned, Lithuania and the EU-15 should converge because the majority of literature confirms that the change of household consumption structure is mostly determined by the increased income (Welsch, Kühling 2009, Vistwanathan, Rosa 2010, Feng, Zou, Wei 2011) and by the prices which are partially relevant to the European integration process (Yu et al. 2003, Chen, Chou 2010).

Along with an increase in the income higher part of consumption expenditure is addressed to luxury goods, whereas procurement of necessity goods might have a tendency to stabilize (Selvanathan, Selvanathan 2003, Lyons, Mayor, Tol 2009) resulting in changes of consumption structure (Clements, Wu, Zhang 2006, Duarte et al. 2010, Feng, Zou, Wei 2011). Increase in prices can lead to significant 
changes regarding the household consumption and its structure (Schleich, Hillenbrand 2008, Fisher, Otto, Voss 2010). According to consumption response to prices, different categories of consumption are divided into price sensitive and non-sensitive groups. Luxury goods and services usually tend to be more price sensitive than necessities (Selvanathan, Selvanathan 2003, Lyons, Mayor, Tol 2009).

The basic aim of this paper is to analyze differences in consumption structure of Lithuania and the EU-15 and to evaluate the course of their convergence. Moreover, this paper pursues a goal of revealing what implications are observed for environmental impact by the growth of household consumption and changes in its structure.

\section{Data and methodology issues}

This study covers the period from the beginning of recovery of Lithuanian economy up to the current financial crisis (1995-2007). The structure of household consumption was divided according to the Classification of Individual Consumption According to Purpose (COICP) and the household consumption expenditure categories were split into 11 groups: food and non-alcoholic beverages, clothing and footwear, housing (water, electricity, gas and other fuels), furnishings and household equipment (furnishings, household equipment and routine maintenance of the house), health, transport, communication, education, recreation and culture, restaurants and hotels, miscellaneous goods and services. Data for measuring the structure of household consumption expenditure were used in current prices and obtained from statistical offices of the EU (Eurostat). To identify alterations of consumption patterns of Lithuania, the household consumption expenditure was used by the categories at constant prices per resident. To estimate response to disposable income (in constant prices) and prices variance for household consumption the data were obtained from statistical offices of Lithuania.

To evaluate the convergence of Lithuanian household consumption expenditure structure and those of the EU-15, an X-convergence approach (Wibber and Whites, 2009) is applied. The Xconvergence refers to comparison of two periods of time and countries. The values of the $\mathrm{X}$-convergence for different consumption categories are calculated as follows (Eq. 1):

$$
X_{i, j}=\frac{y_{i, t+k}-y_{j, t+k}}{y_{i, t}-y_{j, k}}
$$

where:

$y$ - percentages of the household consumption expenditure categories for countries $i$ (EU-15 average) and $j$ (Lithuania);

$t$ - beginning of the analyzed period;

$t .+k-$ end of the analyzed period.
The closer the X-convergence values are to zero, the more the analyzed and other countries converge. On the contrary, the closer the X-convergence values are to 1 or -1 , the weaker is convergence. The values of the $\mathrm{X}$-convergence above 1 or -1 are indicators of divergence. Finally, if the $\mathrm{X}$-convergence values are negative, it means that the countries according to the share of expenditure for relevant consumption category are switching their positions, which means that at the beginning of the analyzed period a certain country had a larger share of expenditure for particular consumption categories, but at the end of that period of time its share of expenditure for that given consumption category is lower than that of the compared country.

To evaluate consumption expenditure response to main determinants - disposable income and prices the coefficient of elasticity is used. The elasticity coefficient is considered to be the ratio of the percentage change in consumption to the percentage change in disposable income or prices. For this purpose linear regression of log-transformed indicators of consumption and disposable income (or prices) is calculated and the coefficient $\beta$ from regression could be directly read as elasticity coefficient (Wilkie, Godoy 2001, Hupkova et. al. 2009, Gerbens- Leenes et. al. 2010, Zhou et. al. 2011). Thus the elasticity estimation equation is specified as follows (Eq. 2):

$$
\ln (Y i)=\alpha+\beta \ln (I) \operatorname{or} \ln (P i)
$$

where:

$\ln (Y i)$ - household consumption expenditure for category $i$ in constant prices;

$\ln (I)$ - disposable income in constant prices;

$\ln (P i)$ - price of consumption category $i$.

$\beta$ - coefficient shows the value of disposable income and price elasticity.

For different determinants - disposable income and prices, coefficient of elasticity $\beta$ conveys different meanings. In the case of disposable income, when $0<$ $\beta<1$, it shows inelastic consumption, when consumption grows less than disposable income. The commodities in possession of this value of elasticity coefficients are usually attributed to the necessities. The value of $\beta>1$ displays that response of consumption to increased income is elastic, i.e. the consumption of this category grows faster than the income and it is usually typical of luxury goods.

In elasticity estimation of prices, the negative coefficient $(\beta<0)$ displays that in the case of price growth consumption decreases However, the negative ratio between consumption and prices could also show a price reduction and a consumption increase, thus it depends on the course of price changes. On the contrary, the positive elasticity coefficient of prices response to household consumption categories indicates the growth in consumption along with the rise in prices. The value of $0<\beta<1$ shows inelastic response which means that despite a price increase the consumption grows, but slower than a price increase 
does. The commodities in possession of inelastic response of prices growth are attributed to rather expensive and price sensitive consumption groups. The elastic response to consumption of price growth is indicated by coefficient $\beta>1$. It displays that consumption grows faster than prices rise up and it shows that commodities are rather cheap and consumption is tending to grow faster despite the growth in prices.

The last part of the study is devoted to the analysis of the environmental impact related to distinct household consumption categories regarding the intensities of acidifying compounds and greenhouse gas emissions. The rough evaluation of consumption related environmental impact is based on the the outcomes of the special study (2010) in 9 EU countries - Austria, Czech Republic, Germany, Denmark, France, Italy, Netherlands, Portugal and Sweden. The Environmental Input-Output-Analysis (EIOA) - as an analytical tool to integrate environmental pressures into macro-economic modelling (compatible to National Accounts) is applied. In this analysis direct and indirect emissions of acidifying compounds and greenhouse gases along the production chains ending in final products are evaluated (including domestically produced and imported goods). From the NACE classification they are converted into 12 consumption categories according to the Classification of Individual Consumption According to Purpose (COICOP).

With references to these data the rough estimation of the aggregate emissions of acidifying compounds and greenhouse gases in Lithuania has been performed for distinct household consumption categories in two scenarios.

According to the first (hypothetic) scenario it is presumed that the structure of consumption does not experience any changes and consumption in all categories grows up at the same rate as total household consumption (stable structure). Second scenario is based on real growth of consumption categories, which conveys real changes in consumption structure during the period of 19952007. The aggregate Lithuanian environmental impact of household consumption for both scenarios is calculated summing up the values of the distinct consumption categories expenditure multiplied by a corresponding value of emission intensities (greenhouse gas emissions, acidification).

\section{Results}

\section{1. Structure of Lithuanian and EU-15 household consumption expenditure and their convergence}

Structure of Lithuanian consumption expenditure in comparison with the EU-15 had essential differences at the beginning of the analyzed period (Fig. 1.). In 1995 major differences were observed in a share of household expenditure for food and non-alcoholic beverages. For this consumption category Lithuanians allocated three times bigger part of expenditure $-44 \%$ as compared to $14 \%$ in the EU15. Considering almost all other consumption categories, citizens of the EU-15 countries allocated the bigger share of expenditure than Lithuanians. Approximately a three times bigger share of home budget was allocated in the EU-15 than in Lithuania for restaurants and hotels, and for miscellaneous goods and services. The share of expenditure for recreation and culture, also for furnishings and household equipment in the EU-15 exceeds approximately twice that in Lithuania. Least disparities in the share of home budget of Lithuanians and EU-15 citizens are typical of housing, clothing and footwear, also of health care categories.

Hence, it can be seen that in 1995 the shares of expenditure for two main necessity categories - food and housing comprised two thirds of general expenditure in Lithuania, whereas in the EU-15 these two positions comprised only one third of general expenditure. As to luxury items, such as recreation and culture, restaurants and hotels, communication, education also for miscellaneous goods and services they amounted to almost three times larger budget share in the EU-15 than in Lithuania.

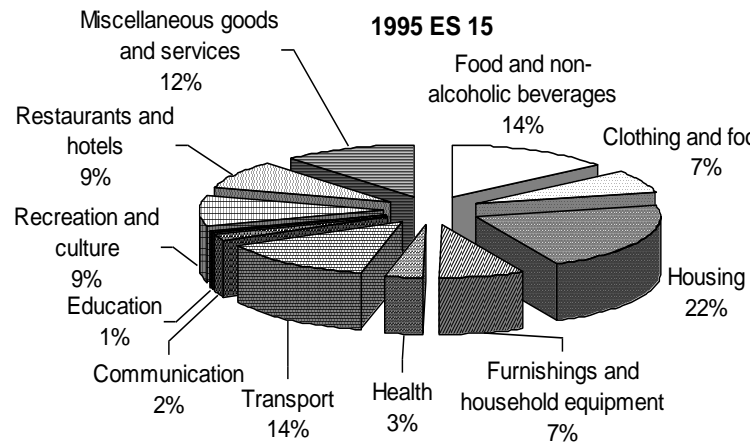

Fig.1.

Structure of household consumption expenditure in Lithuania and the EU-15 countries (1995)

In the EU-15 consumption structure did not experience any essential changes during the analyzed 1995-2007 year period. However, it changed rather drastically in Lithuania. It can be seen (Fig. 2) that in Lithuania the share of expenditure for food and nonalcoholic beverages decreased most and in 2007 it 
made only $26 \%$, though it still occupied a largest share. In the EU-15 countries the most essential increase and approaching the share of home budget was for furnishings and equipment, transportation, recreation and culture, and other luxury items with an exception of expenditure for restaurants and hotels.

Thus, in 2007 according to the share of furnishings and household equipment Lithuania and the EU-15 were equalized, whereas in terms of clothing and footwear Lithuania overtook Old Member States. On the contrary, the budget share of expenditure for housing in Lithuania decreased by one third and comprised 14\% in 2007. While during the analyzed period in the EU-15 the share of this expenditure category increased by $1 \%$ and expenditure for housing occupied the largest part of general expenditure.
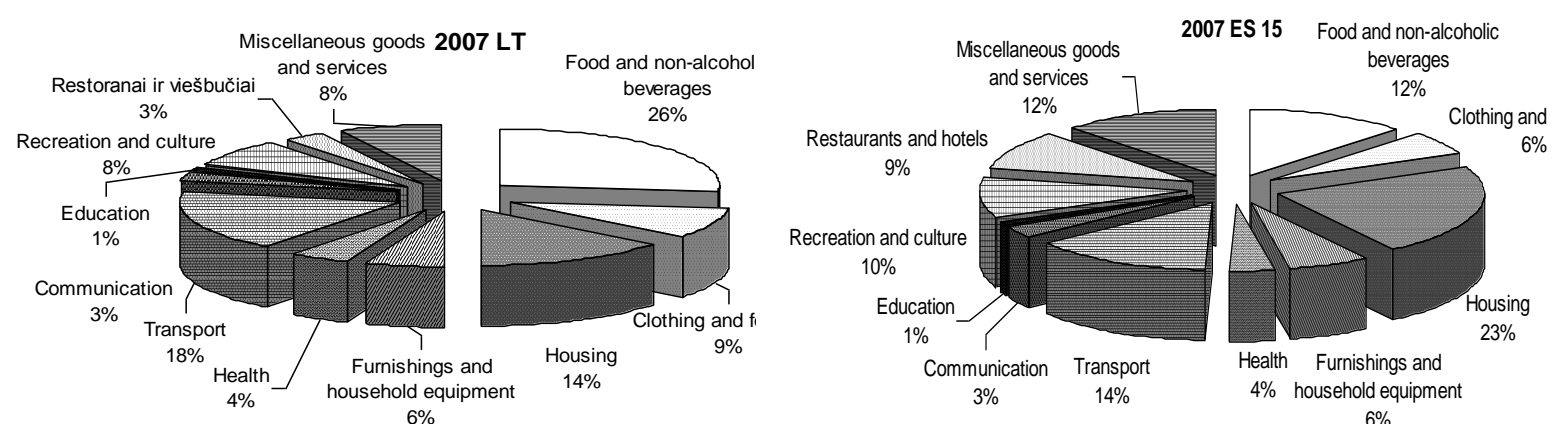

Fig.2. Structure of household consumption expenditure in Lithuania and the EU-15 countries (2007)

To estimate the convergence level for home budget structure in both Lithuania and the EU-15, the $\mathrm{X}$-convergence approach was applied. As it has been presented in methodology, the closer value of $\mathrm{X}$ convergence to zero indicates a faster convergence process. And if the value is above 1, it shows divergence of household consumption expenditure structure.

Figure 3 depicts that from all eleven household consumption expenditure categories Lithuania converged with the EU-15 by seven of them. The strongest convergence is noticed in the budget share for communication, furnishings and household equipment, thus displaying that Lithuania is approaching the EU-15 most of all in the latter categories. Convergence of an expenditure share for recreation and culture, food, non-alcoholic beverages, miscellaneous goods and services is also clearly seen, but the values of $\mathrm{X}$-convergence are bigger than those of the above described consumption categories, indicating the slower convergence rate. Convergence was the weakest in a share of transport expenditure and the value of $\mathrm{X}$-convergence was negative. This result reveals that Lithuania has overtaken and even surpassed the EU-15 in the budget share for this item

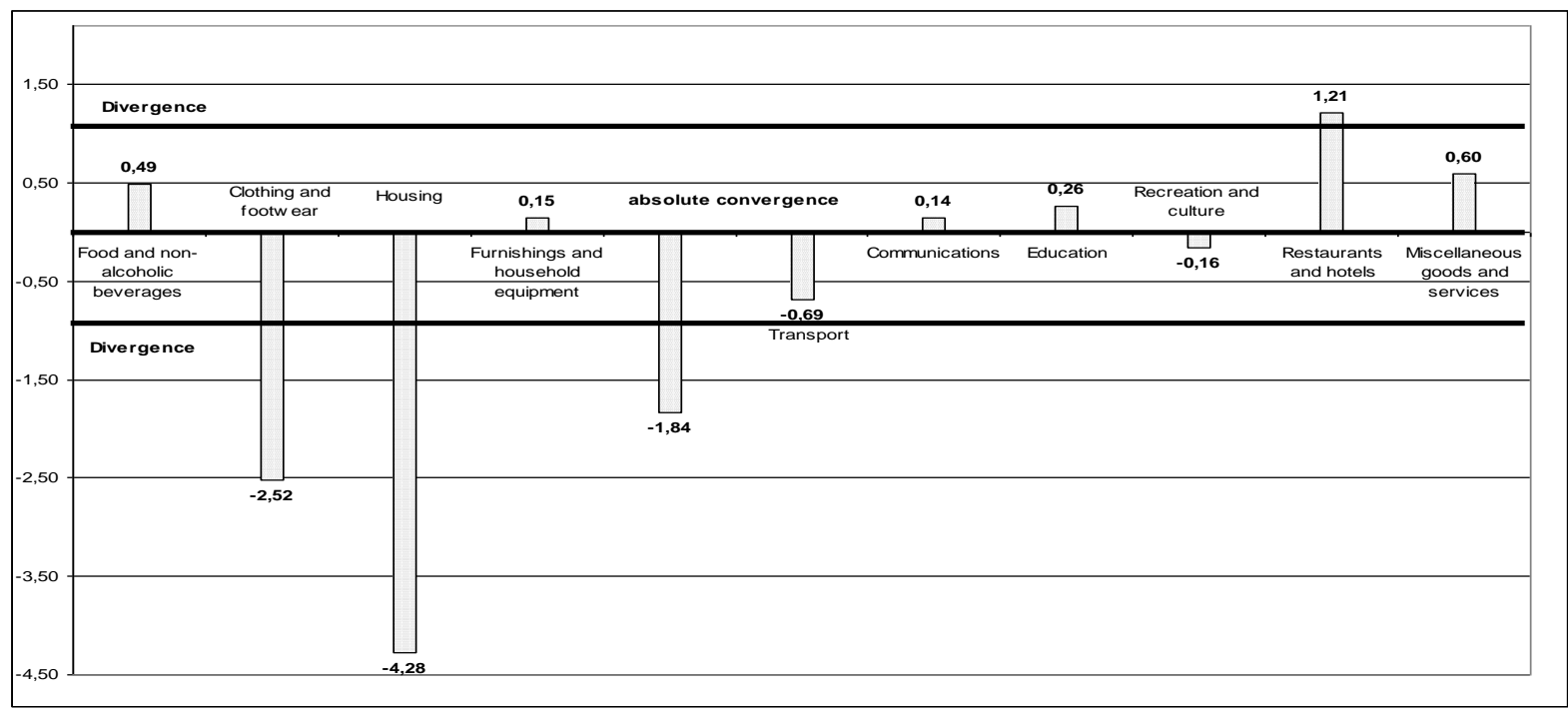

Fig.3. X-convergence level for different home budget items between Lithuania and EU-15 during 1995-2007

Meanwhile, Lithuania diverged from the Old Member States by four categories out of all household consumption expenditure categories. The weakest divergence occurred of household expenditure for restaurants and hotels. In the case of the budget shares for housing, health, clothing and footwear the biggest 
and negative divergences have occurred. The most essential divergence of all consumption expenditure categories is evident in a housing item. In this case, the negative values of $\mathrm{X}$-convergence reveal that in Lithuania in those consumption categories the budget shares declined, while in Old Members they grew-up.

Summing up the presented data, a conclusion can be drawn that in general the essential convergence of the home budget structure in Lithuania and the EU15 took place during 1995-2007.

\subsection{Growth in Lithuanian household consumption expenditure and its determinants}

In Lithuania general household consumption expenditure per capita (in constant prices) increased 2.7 times during the period of 1995-2007. A quite different rate of consumption increase was characteristic of different consumption categories (Fig.4). The most essential growth in expenditure was observed for recreation and culture and in 2007, for this consumption category citizens of Lithuania spent 8.6 times more than in 1995. The expenditure for furnishings and household equipment and also for education rose very fast as well, and it has approximately increased six times. Very low growth was typical of expenditure for restaurants and hotels (2.1 times), also for food and non-alcoholic beverages (2.3 times). The fact that growth in expenditure for food and non-alcoholic beverages was one of the lowest could be explained that when the basic need for food approaches the level of satisfaction, expenditures for this consumption group do not grow up so fast (Yu et al. 2003, Gerbens-Leenes et al. 2010). Only the real (in constant prices) expenditure for housing underwent almost no changes during the analyzed period.

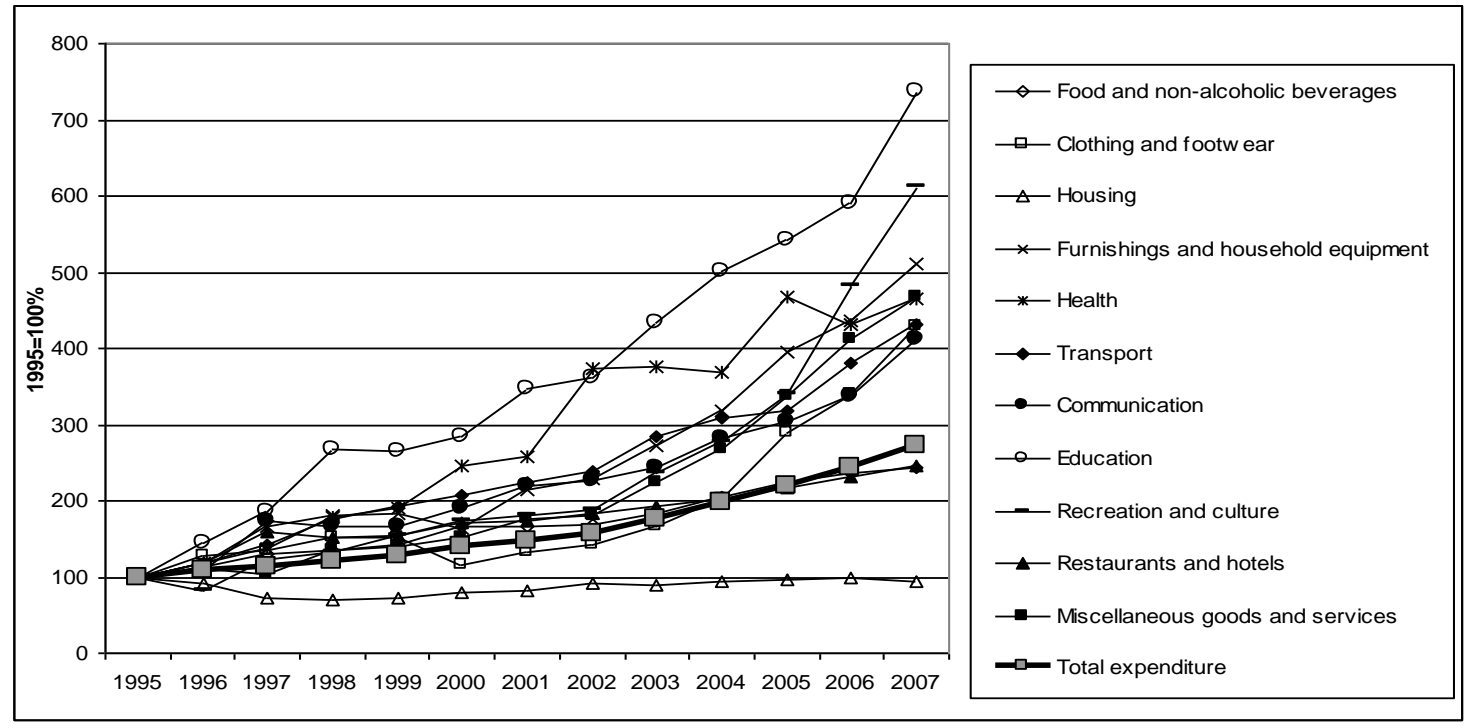

Fig.4.

Lithuanian household consumption expenditure for consumption purposes (COICOP), at constant prices during 1995-2007 (1995=100\%)

The household consumption expenditure is mostly influenced by disposable income and price changes, which are partially relevant to the integration to the EU (Selvanathan, Selvanathan 2003, Clements, Wu, Zhang 2006, Lyons, Mayor, Tol 2009, Duarte et al. 2010, Feng, Zou, Wei 2011, Liobikiene, Mandravickaite 2011). Considering the trend of growth in disposable income, as depicted in Figure 5, during the analyzed period the income increased 2.5 times, however an increase in household consumption expenditure was higher 2.7 times.

Increase in prices of distinct consumption categories differed greatly. The highest growth in prices was observed for communication and housing. Meanwhile the prices for recreation and culture, clothing and footwear also for furnishings and household equipment were reducing from 1998 to 2004 whereas the prices for clothing and footwear continued declining until 2007.
In order to evaluate elasticity of consumption response to alterations of disposable income and prices, elasticity coefficient $\beta$ is used as presented in methodology. As it seen from Table 1, response to a disposable income increase for consumption of food and non alcoholic beverages, restaurants and hotels also housing was inelastic (coefficient of elasticity $\beta<1)$. These were commodities whose expenditure increased less than their income increase. Similar results concerning food and non-alcoholic beverages also housing were gained by other authors (Selvanathan,. Selvanathan 2003, Clements, Zhang, 2006). Research in Ireland has shown that only for food consumption inelastic response is characteristic to increase of income (Lyons, Mayor, Tol, 2009). These results reveal that in Lithuania as well as in other countries the consumption of necessities as food and non-alcoholic beverages, also housing, is tending to increase less than disposable income. However, during the period of 1995-2007 the consumption for 
restaurants and hotels, which is considered as luxury, grew slower than disposable income. It conveys that Lithuanians preferred to spend more for the other consumption categories than for restaurants and hotels.

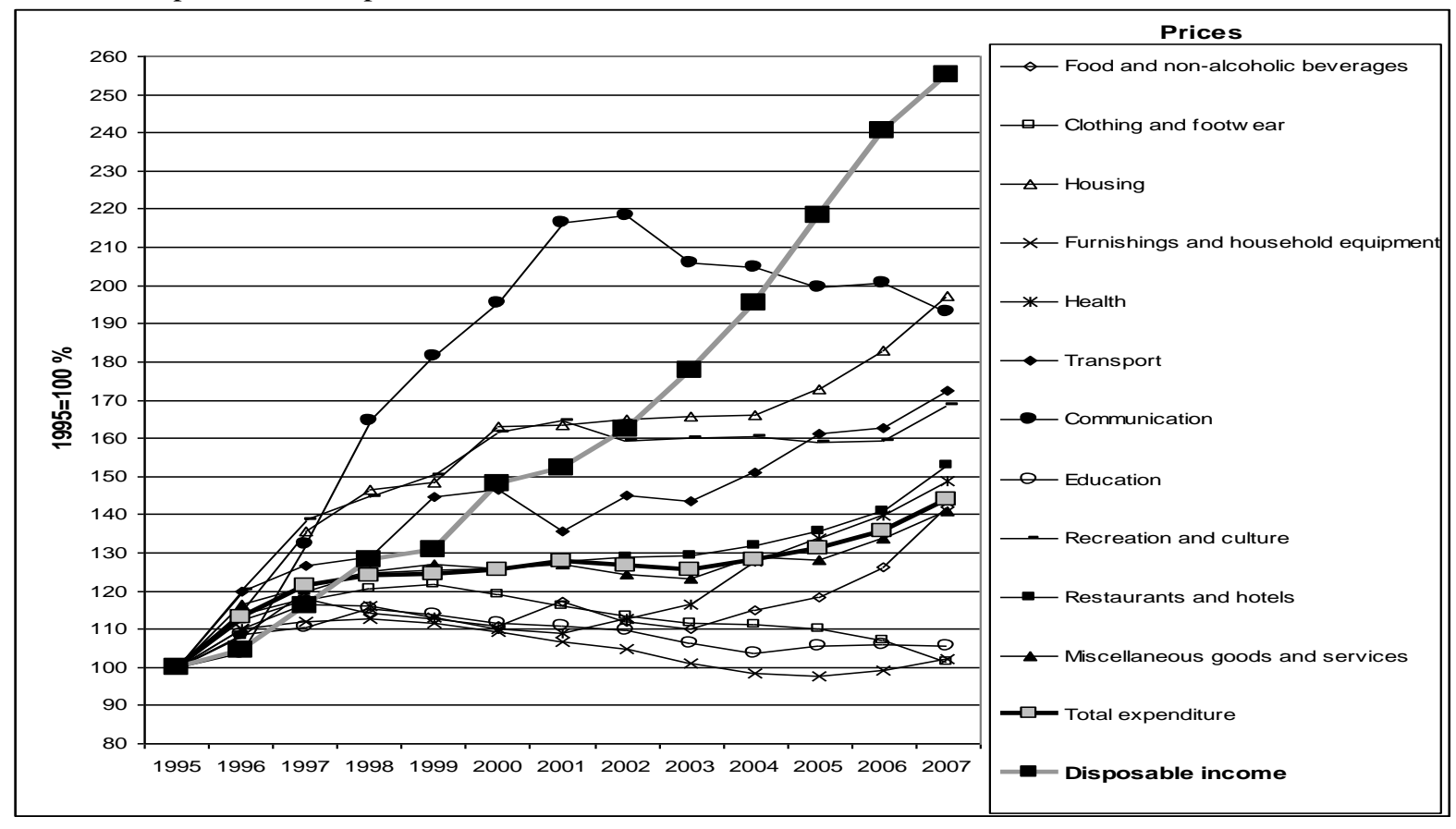

Fig.5.

Growth rates of prices of distinct household consumption categories and disposable income (in constant prices) in Lithuania during 1995-2007 (1995=100\%)

In all other consumption categories elastic response to an income increase is characteristic $(\beta>1)$ indicating a faster increase in consumption expenditure than that in the income. As it was pointed out by S. Lyons, K. Mayor, R. S. Tol (2009), when the country reached a threshold level of income, consumers are able to spend more for consumption categories which are considered luxuries. According to our study the biggest rise in consumption, when the income increased by $1 \%$, was observed for education $(1.9 \%)$ and for recreation and culture $(1.85 \%)$.

Table 1.

Elasticity of consumption response to alterations of disposable income and prices $(\boldsymbol{\beta})$

\begin{tabular}{|c|c|c|c|c|}
\hline & \multicolumn{2}{|c|}{$\begin{array}{l}\text { Disposal } \\
\text { incomes }\end{array}$} & \multicolumn{2}{|c|}{ Prices } \\
\hline & $\beta$ & $R^{2}$ & $\beta$ & $R^{2}$ \\
\hline $\begin{array}{l}\text { Food and non- } \\
\text { alcoholic beverages }\end{array}$ & $0.9^{*}$ & 0.98 & $2.1 *$ & 0.46 \\
\hline Clothing and footwear & $1.3^{*}$ & 0.79 & -3. & 0.21 \\
\hline Housing & 0.18 & 0.18 & 0.07 & 0.02 \\
\hline $\begin{array}{l}\text { Furnishings and } \\
\text { household equipment }\end{array}$ & $1.6^{*}$ & 0.96 & $-5.3 *$ & 0.36 \\
\hline Health & $1.7 *$ & 0.92 & $3^{*}$ & 0.54 \\
\hline Transport & $1.4^{*}$ & 0.97 & $2.3 *$ & 0.9 \\
\hline Communication & $1.3^{*}$ & 0.95 & $0.9^{*}$ & 0.6 \\
\hline Recreation and culture & $1.85^{*}$ & 0.94 & -1.4 & 0.01 \\
\hline Education & $1.9^{*}$ & 0.97 & $2.4^{*}$ & 0.54 \\
\hline Restaurants and hotels & $0.8^{*}$ & 0.91 & $1.9^{*}$ & 0.93 \\
\hline $\begin{array}{l}\text { Miscellaneous goods } \\
\text { and services }\end{array}$ & $1.7 *$ & 0.98 & $4.5^{*}$ & 0.61 \\
\hline
\end{tabular}
$* p<0.05$

Considering the consumption response to prices it is observed that in Lithuania the negative elasticity coefficient was observed for furnishings and household equipment, recreation and culture also for clothing and footwear, indicating that consumption in these consumption categories during the analyzed period grew, while their prices decreased (Table 1). Considering the consumption categories their response to an increase in prices was elastic i.e. the consumption increased more than prices fell down

Only a response of consumption expenditure for housing (insignificant) and communication to an increase in prices was inelastic. Thus, the consumption in these categories increased slower, especially for housing than the prices did and it conveys that housing and communication are rather expensive and sensitive to price growth. Meanwhile the elastic response to prices was characteristic of restaurants and hotels $(1.9 \%)$. food and non-alcoholic beverage $(2.1 \%)$. transport $(2.3 \%)$. health $(3 \%)$. education $(2.4 \%)$ and of miscellaneous goods and services $(4.5 \%)$. These results display that in Lithuania the latter consumption categories were rather cheap and less sensitive to price growth. Despite the price growth citizens are tending to spend more particularly for miscellaneous goods and services (insurance. social security. etc.) health and education (Table 1).

\subsection{Implications for environmental impact due to alteration of household consumption expenditure structure in Lithuania}

Taking into consideration that for distinct consumption categories different environmental 
impact is characteristic (Kerkhof. Nonhebel. Moll 2009, EEA 2010, Feng. et. al. 2011, ETC/SCP 2011) evaluation of changes of environment impact along with changes of consumption structure is important. Whereas in Lithuania the analysis of environmental impact of distinct consumption categories during the entire life-cycle was not performed. Results of the European Environmental Agency study (2010) based on input-output analysis were used for rough evaluation of the intensity of greenhouse gases and acidifying compounds emissions for distinct household consumption categories.

According to the results obtained from this evaluation (Table 2) it is evident that food and nonalcoholic beverages category is one of the most polluting consumption categories in possession of the highest emission intensities for both - green house gases and acidifying compounds. The consumption categories as transport and housing in regard to emissions of greenhouse gases and acidifying compounds could be attributed to a highly polluting consumption group as well. The residual consumption categories have moderate emission intensities. The lowest emission intensities were observed for education and miscellaneous goods and services.

Thus, referring to the EEA (2010) results, the rough environmental impact of aggregate Lithuanian household consumption in 1995 and in 2007 was evaluated. Evaluation was done for two scenarios. In the first (hypothetic) scenario it was presumed that the structure of consumption did not experience any changes and consumption in all categories grew up at the same rate as total consumption (stable structure). The second scenario is based on real growth of consumption categories and real changes in the structure during the period of 1995-2007.

Table 2. Emission intensities of greenhouse gas and acidification compounds for distinct consumption categories (EEA 2010)

\begin{tabular}{|l|r|r||}
\hline & $\begin{array}{c}\text { Greenhouse } \\
\text { gas kg CO2 } \\
\text { equiv/Euro }\end{array}$ & $\begin{array}{c}\text { Acidification } \\
\text { compounds } \\
\text { g SO2 } \\
\text { equiv/Euro }\end{array}$ \\
\hline Food \& non-alcoholic beverages & 1.1 & 12.8 \\
\hline Transport & 1.2 & 4.7 \\
\hline Housing & 1.0 & 1.8 \\
\hline Clothing and footwear & 0.4 & 1.5 \\
\hline Restaurants and hotels & 0.4 & 2.7 \\
\hline $\begin{array}{l}\text { Furnishings and household } \\
\text { equipment }\end{array}$ & 0.3 & 1.3 \\
\hline Recreation and culture & 0.3 & 1.0 \\
\hline Health & 0.2 & 0.7 \\
\hline Communication & 0.2 & 0.6 \\
\hline Education & 0.1 & 0.4 \\
\hline $\begin{array}{l}\text { Miscellaneous goods and } \\
\text { services }\end{array}$ & 0.1 & 0.4 \\
\hline
\end{tabular}

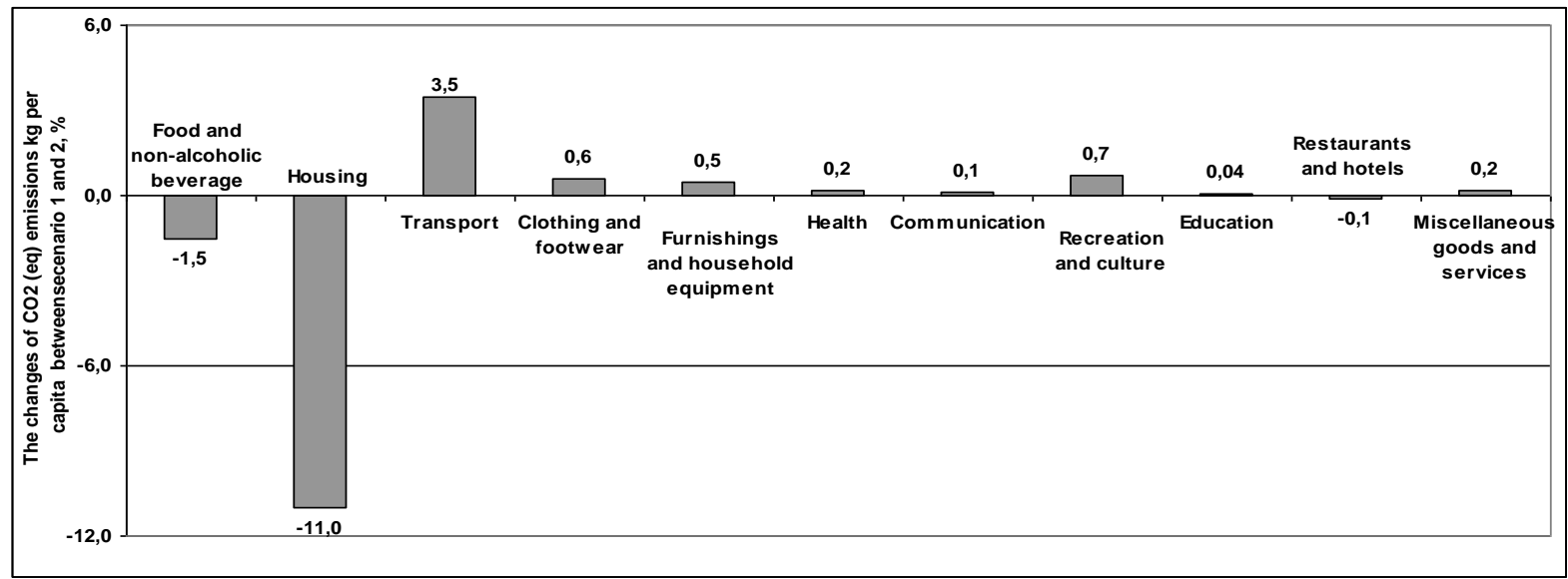

Fig.6.

Changes in $\mathrm{CO}_{2}$ (eq.) emissions for distinct household consumption categories related to changes in consumption structure (1995-2007)

Regarding greenhouse gases (GHG) emissions it was estimated that in the case of a first scenario (stable consumption structure) along with an increase in general consumption the aggregate emissions of greenhouse gases would increase 2.7 times during the analyzed 1995-2007 period. In the case of a second scenario, (real changes in consumption structure) and referring to the EEA (2010) emission intensity, the growth of aggregate GHG emissions during the same time increased roughly about 2.3 times i.e. about 19 $\%$ less than in the case of stable consumption structure. Figure 6 indicates that along with changes in consumption structure the emissions of greenhouse gases decreased mostly for housing, whereas the consumption growth of this category was the lowest (Fig. 4) and the intensity of greenhouse emissions was one of the highest (Table 2). The decrease in greenhouse gas emissions was also observed for food and non-alcoholic beverages and for restaurants and hotels by $1.5 \%$ and $0.1 \%$ respectively. However, changes in consumption structure caused an increase in GHG emissions for other consumption categories, particularly for transport. Nevertheless, it did not offset decrease in greenhouse emissions which occurred between two scenarios for housing, food and beverage also for restaurants and hotels. 


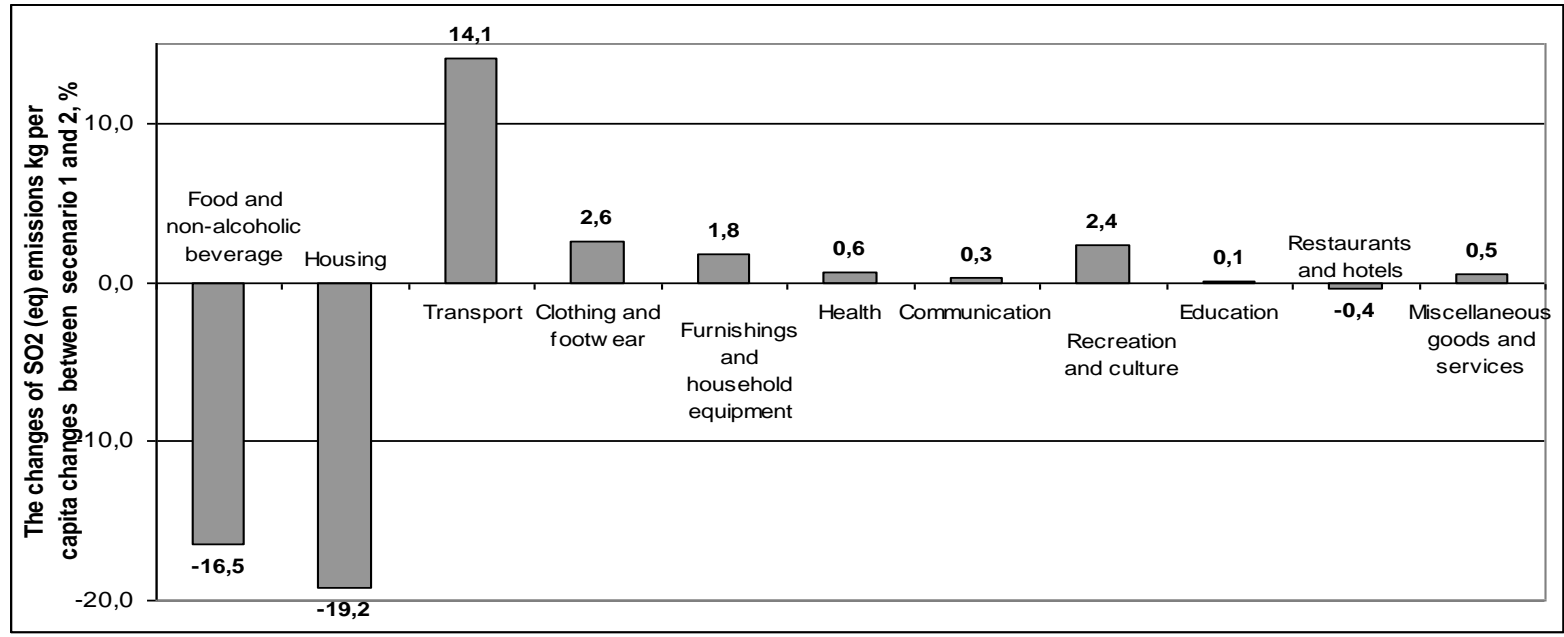

Fig.7. Changes of $\mathrm{SO}_{2}$ (eq.) emissions for distinct household consumption categories related to changes in consumption structure (1995-2007)

Regarding the emissions of acidifying compounds, changes in consumption structure resulted in decrease in their emissions roughly by 6 $\%$. The biggest decrease in AC emissions similar to the case of GHG was observed for housing and food and beverages consumption categories and the biggest increase - for transport.

\section{Conclusions}

During the period of 1995-2007 the household consumption in Lithuania rose up by 2.7 times. A substantial growth in consumption expenditure was observed to luxuries as recreation and culture (7 times), education (6 times) and slowest growth - to necessities as food and non alcoholic beverages, housing.

Different growth in distinct household consumption expenditure categories has determined the consumption structure changes in Lithuania. Thus, during the analyzed period Lithuania converged towards the Old Member States by two thirds in household consumption structure categories.

Response of most consumption categories considered as necessities (food. housing. etc.) to growth in the income was inelastic i.e. consumption of these categories grew up slower than income. On the contrary, in consumption categories which are considered luxuries (recreation and culture. miscellaneous goods and services. education) elastic response to the income increase was characteristic and the consumption in these categories grew up faster than the income.

In general, during the analyzed period in Lithuania significant growth was typical of consumption categories with lower environmental impact. Referring to the EEA study (2010) the changes in consumption structure decelerated an increase in emissions of greenhouse gases roughly by $19 \%$ and acidifying compounds by $6 \%$ during 1995 2007

\section{References}

Chen, N. H., Chen, S. S., Chou, Y. H. House prices, collateral constraint and the asymmetric effect on consumption. Journal of Housing Economics, 2010, Vol. 19. pp. 26-37. http://dx.doi.org/10.1016/j.jhe.2009.10.003

Clements, K. W., Wu, Y., Zhang. J. Comparing international consumption patterns. Empirical Economics, 2006, Vol. 31. pp. 1-30. http://dx.doi.org/10.1007/s00181005-0012-y

Duarte, R., Mainar, A., Sanchez-Choliz, J. The impact of household consumption patterns on emissions in Spain. Energy Economics, 2010, Vol. 32. pp. 176-185. http://dx.doi.org/10.1016/j.eneco.2009.08.007

EEA. 2010. The European environment - state and outlook 2010: Synthesis. State of environment report No 1. p. 113.

ETC/SCP (European Topic Centre on Sustainable Consumption and Production). 2011. Key message on material resource use and efficiency in Europe: Insights from environmentally extended input-output analysis and material flow accounts. Working paper 3. p. 31.

Feng, Z. H., Zou, L. L., Wei, Y. M. The impact of household consumption on energy use and $\mathrm{CO}_{2}$ emissions in China. Energy , 2011, Vol. 36. pp. 656-670. http://dx.doi.org/10.1016/j.energy.2010.09.049

Fisher, L. A., Otto, G., Voss, G. M. The response of Australian consumption to housing wealth. Journal of Macroeconomics, 2010, Vol. 32. pp. 284-299. http://dx.doi.org/10.1016/j.jmacro.2009.06.004

Gerbens-Leenes, P. W., Nonhebel, S., Krol, M. S. Food consumption patterns and economic growth. Increasing affluence and the use of natural resources. Appetite , 2010, Vol. 55, No .3. pp. 597-608.

Hupkova, G., Bieli, K P, Turcekova, N. Structural changes in the beef meat demand in Slovakia and demand elasticity estimation. Agricultural Economics, 2009, Vol. 55. No. 8. pp. 361-367.

Jacson, T. 2006. The earth scan reader in sustainable consumption. London: Sterling. VA. p. 402.

Kerkhof ,A. C., Nonhebel, S., Moll, H. C. Relating the environmental impact of consumption to household expenditure: An input-output analysis. Ecological Economics, 2009, Vol. 58. pp. 1161-1170.

Kok, R., Benders, R. M. J., Moll, H. C. Measuring the environmental load of household consumption using some methods based on input-output energy analysis: A comparison of methods and a discussion of results. Energy 
Policy, 2006, Vol. 34. pp. 2744-2761. http://dx.doi.org/10.1016/j.enpol.2005.04.006

Kuhndt, M. 2008. Sustainable Consumption and Production along Global Value Chains: Trends and Focus Areas. UNEP Wuppertal Institute Collaborating centre on sustainable consumption and production.

Liobikienè, G., Mandravickaite, J. Achievements of Lithuanian sustainable development during the integration process into the European Union. Technological and Economic Development of Economy, 2011, Vol. 17, No. 1. pp. 62-73 http://dx.doi.org/10.3846/13928619.2011.554000

Lyons, S., Mayor, K., Tol, R. S. J. Convergence of consumption patterns during macroeconomic transition: A model of demand in Ireland and the OECD. Economic Modeling, 2009, Vol. 26. pp. 702-714. http://dx.doi.org/10.1016/j.econmod.2009.01.017

Nash, H. A. The European Commission's sustainable consumption and production and sustainable industrial policy action plan. Journal of Cleaner Production, 2009, Vol. $17 . \quad$ pp. 496-498. http://dx.doi.org/10.1016/j.jclepro.2008.08.020

Schleich, J., Hillenbrand, T. Determinants of residential water demand in Germany. Ecological Economics, 2009, Vol. 58. pp. 1756-1765. http://dx.doi.org/10.1016/j.ecolecon.2008.11.012

Selvanathan, E. A., Selvanathan, S. Similarities in the Consumption Patterns of the Five Asian Tigers. Asian Economic Journal, 2003, Vol. 17, No 31. pp. 297-323. http://dx.doi.org/10.1111/j.1467-8381.2003.00188.x

The Lithuanian strategy for sustainable development. 2009. Approved by Resolution No.1247 of September 16 . 2009 of the Government of the Republic of Lithuania.

Viswanathan, M., Rosa, J. A. Understanding subsistence marketplaces: Toward sustainable consumption and commerce for a better world. Journal of Business Research, 2010, Vol. 63. pp. 535-537. http://dx.doi.org/10.1016/j.jbusres.2009.06.001

Webber, D. J., White, P. An alternative test to check the validity of convergence results. Applied Economics Letters, 2009, Vol. $16 . \quad$ pp. 1825-1829. http://dx.doi.org/10.1080/13504850701719579

Welsch, H., Kuhling, J. Determinants of proenvironmental consumption: The role of reference groups and routine behaviour. Ecological Economics, 2009, Vol.
69. pp.

http://dx.doi.org/10.1016/j.ecolecon.2009.08.009

166-176.

Wilkie, D. S., Godoy, R. A. Income and price elasticities of bushmeat demand in lowland in Amerindian societies. Conservation Biology, 2001, Vol. 15, No. 3. pp. 761-769).

1739.2001.015003761.x http://dx.doi.org/10.1046/j.1523-

Yu, W., Hertel, T. W., Preckel, P. V., Eales, J. S. Projecting world food demand using alternative demand systems. Economic Modelling, 2003, Vol. 21. pp. 99-129. http://dx.doi.org/10.1016/S0264-9993(02)00086-X

Zhou, Z., Su, Y., Gao, J., Xu, L., Zhang, Y. New estimates of elasticity of demand for healthcare in rural Chine. Health Policy, 2011, in press. http://dx.doi.org/10.1016/j.healthpol.2011.09.005

Genovaitė Liobikienė - PhD student at Vytautas Magnus University. Department of Environmental Sciences. Lithuania.

Main research area: sustainable consumption. convergence. sustainable development.

Address: $\quad$ Vileikos Str. 8

Fax: $\quad$ +3707327904

Tel.: $\quad+3707327904$

E-mail: $\quad$ g.liobikiene @ gmf.vdu.lt

Romualdas Juknys - professor at the Department of Environmental Sciences. Vytautas Magnus University. Lithuania.

Main research area: sustainable development. integrated impact of anthropogenic climatic and environmental changes to vegetation of forest and agro ecosystems

Address: $\quad$ Vileikos Str. 8.

LT-44404. Kaunas. Lithuania

Fax: $\quad$ +370 $\quad$ +3707327904

Tel.: $\quad+3707327904$

E-mail: $\quad$ r.juknys@gmf.vdu.lt 


\title{
Namų ūkio išlaidų struktūros konvergencija: jos įtaka poveikiui aplinkai Lietuvoje
}

\author{
Genovaitė Liobikienė, Romualdas Juknys
}

Vytauto Didžiojo universitetas. Gamtos mokslu fakultetas

(gauta 2012 m. vasario mèn., priimta spaudai 2012 m. birželio mèn.)

Straipsnio tikslas - nustatyti Lietuvos namų ūkio išlaidų struktūros konvergenciją prie ES15 ir itaką poveikiui aplinkai. Bendrosios namų ūkio išlaidos 1995-2007 m. padidèjo 2,7 karto. Šiuo laikotarpiu didžiausios prabangos prekių: rekreacijos ir kultūros bei švietimo, išlaidos. Mažiausios būtinujų prekių: maisto ir būsto, išlaidos. Taip pat buvo nustatyta, kad Lietuva pagal du trečdalius vartojimo kategorijų artejo prie ES senbuvių. Analizuojant disponuojamu pajamų atsaką vartojimui, buvo nustatyta, kad būtinujų prekių, kurioms skiriama didžioji išlaidų dalis, vartojimui atsakas buvo neelastingas, t. y. jos buvo vartojamos lěčiau nei didejo gyventoju pajamos. Prabangos prekių (rekreacijos ir kultūros, švietimo, kitų paslaugų) vartojimui šis atsakas buvo elastingas, t. y. jos buvo vartojamos greičiau nei didejjo gyventoju pajamos. Taigi šiuo tiriamuoju laikotarpiu Lietuvos gyventojai daugiau vartojo tų prekių, kurių poveikis aplinkai buvo mažesnis. Remiantis EEA (2010) energijos intensyvumo duomenimis, buvo apskaičiuota, kad 1995-2007 m. pasikeitus vartojimo struktūrai klimato kaitą sukeliančių dujų emisijos augimas apytikriai sumažèjo 19 proc., o rūgštinančių medžiagų kiekis - apie 6 proc. 